MA MAJOR RESEARCH PAPER

Carried away: 'revisioning' feminist film theory toward a radical practice

Submitted by Kimberley Radmacher

Supervisor: Professor Scott Forsyth

The Major Research Paper is submitted in partial fulfillment of the requirements for the degree of Master of Arts

Joint Graduate Programme in Communication \& Culture

Ryerson University - York University

Toronto, Ontario, Canada

April 30, 2004 


\section{Carried away: 'revisioning' feminist film theory toward a radical practice}

The question of women's expression has been one of both self-expression and communication with other women, a question at once of the creation/invention of new images and of the creation/imaging of new forms of community. If we rethink the problem of a specificity of women's cinema and aesthetic forms in this manner, in terms of address-who is making films for whom, who is looking and speaking, how, where, and to whom--then what has been seen as a rift, a division, an ideological split within feminist film culture between theory and practice, or between formalism and activism, may appear to be the very strength, the drive and productive heterogeneity of feminism. ${ }^{1}$

It's difficult to believe that after over 30 years of feminist theory "breaking the glass ceiling" is still a term often heard from women professionals. Still, while women continue to make up a trifling percentage of CEOs in Fortune 500 companies, and are continually paid $72 \%$ of the wages of their male counterparts, ${ }^{2}$ small advances continue to be made by women in both these areas. ${ }^{3}$ Yet, one profession that stands out as persistently keeping women on the outside looking in is mainstream filmmaking, especially directing. Indeed, no woman has ever won an Oscar for directing, and women are rarely nominated in the category, most likely because women direct less than $1 \%$ of

\footnotetext{
${ }^{1}$ de Lauretis, 1990: 296.

${ }^{2}$ Statistics Canada, Perspectives, Spring 2002.

3 "In 2002, women represented 15.7 percent of corporate officers in America, up from 12.5 percent in 2000, and 8.7 percent in 1995." Cited in Kingston, Anne
} 
mainstream films. While women continue to chip their way up the corporate ladder, albeit excruciatingly slowly, women directors of mainstream films are actually declining in numbers. ${ }^{4}$

It is ironic that it should be in the area of filmmaking that women have made such small progress. The implication of feminist film criticism's rifts and divisions, played out in theories of heterogeneity or what makes up a feminist aesthetic, typifies the continuing contribution that feminist criticism has made to critical and cultural studies on a whole. Much current critical theory is indebted to feminist film theory, but in turn, critical, psychoanalytic, poststructuralist and cultural studies' influences on radical feminist theory have effected--or at least influenced--a shift that tends to privilege a critical practice dealing primarily with image/representation. As a result, feminist approaches to media have centred on '[re]reading' popular culture through a narrow feminist paradigm which in film criticism, especially, has meant that dominant critical strategies chiefly have been limited to a political tactic of "reading against the grain," rather than a tactic of producing contemporary feminist films.

Because film, along with other visual media, is such an integral discursive element of societal and cultural production, the relative absence of women's and feminist voices cannot but signify a weak spot in feminist visual cultural theory. Contemporary feminist film critics continue to make important epistemological contributions, but their theories

\footnotetext{
4 "The percentage of women directors dropped dramatically from $11 \%$ in 2000 to $6 \%$ in 2001 ."(Lauzen, $2002,1$.
} 
consistently prove unable to be translated sufficiently into material gain, that is, into opening space for women within the film production machine.

Furthermore, present-day feminist visual cultural theorists have grappled with the seeming indifference toward feminism young academics are bringing into the classroom. Melinda Barlow muses, "women born into the 'postfeminist' generation, if not disturbingly complacent in their sense of privilege, may be drawn to feminist concepts but afraid to identify themselves publicly as feminists." ${ }^{5}$ This sense of complacency is no doubt part of the problem, but it behooves feminist scholarship to find ways to rearticulate feminist concerns so that they are meaningful for young, would-be feminist filmmakers.

The fact that periodicals like Cinema Journal and The National Women's Studies Association Journal (NWSA) have recently published essays like "Rethinking Feminism and Visual Culture," or "Why Feminist Film Theory?" suggests not only unrest within contemporary feminist film criticism, but also a certain readiness to look back at foundational theories in order to move forward. Indeed, a recent issue of Camera Obscura $(54)^{6}$ was dedicated to retracing the steps of feminist video practice's history, especially its height in the mid-70s. However important these examples of nostalgic looking back are to effecting potential "postfeminist" scholars, and continuing feminist scholarship's relevance, the aim of this type of literature is simply to open up further

\footnotetext{
${ }^{5}$ Barlow, 2003: 3 .

${ }^{6}$ Volume 18, Number 3, 2003.
} 
theoretical space, rather than provide potential innovative frameworks in which to foster feminist visual cultural production.

I, too, find encouragement in the fervour of 1970 s feminist [film] criticism and history. To be sure, this was a fecund time for political cultural production in general, and the sense of empowerment expressed by women making their early films during this period is not only inspirational but also instructive. In this essay, I will take up the current feminist epistemological approach of looking back to move forward. I will review some key essays in feminist film criticism's canon and then move on to examine some ways these earlier tracts have been interpreted into contemporary practice. The final section will focus on films made by women, beginning by looking closely at two noncommercial films, Sara Gomez's One Way Or Another and Sally Potter's Thriller, as examples around which to approach and revisit some key theoretical concerns that arose amid the radical, post-' 68 feminist politics and the rise of the women's movement. I find these two films typify potential radical feminist filmic approaches to questions that still plague film theory today. By reassessing texts of the feminist film canon through my analysis of these films, I hope to retrace the philosophical steps that have led feminist film criticism to a type of quandary: it is a philosophy that retains its power by strategically remaining in liminal spaces. 
The publication of Laura Mulvey's much-cited essay "Visual Pleasure and Narrative Cinema," ${ }^{7}$ is generally thought of as marking a pivotal moment when a feminist politics of cinematic representation took off. This period in feminist history looked bright for would-be feminist critics and filmmakers: "By the mid-1970s, feminist film practice-spanning filmmaking collectives, narrative, documentary and experimental films and distribution companies, film festivals, journals, women's studies courses which tracked 'images of women' in Hollywood and European art cinemas or sought to recover lost women's visions by unearthing the feminist subversion of Ida Lupino or Dorothy Arzner-was firmly institutionalized." 8 "Visual Pleasure" provides a model that proposes to account for the inherent differences in men's and women's viewing engagements with mainstream cinema and seeks to create a new space to explain women's marginalization that can not be addressed or transcended through Marxist politics alone. But--and this tends to be elided in responses to the essay--the essay is an instructional guide to the potential feminist filmmaker, to help her recognize and avoid the pitfalls of unquestioningly adopting the patriarchal film language of mainstream cinema.

"Visual Pleasure" has been of interest to media and cultural studies because it is emblematic of a critical move to create a hybrid of Lacanian-Marxist film theory. But a number of responses to the essay, and the theories that followed after it appeared in 1974, have proven to be selective in their approach. Unfortunately, Mulvey chooses to focus mainly on Hitchcock's films, so that reactions to "Visual Pleasure" have tended to be preoccupied with defending Hitchcock. Although Mulvey's take on mainstream film

\footnotetext{
${ }^{7}$ I will refer to the essay as "Visual Pleasure" after this throughout the essay.

"Rabinowitz: 2001, 74
} 
practices has been crucial for moving toward a deeper feminist understanding of the normative, patriarchal social function of conventional cinema, many of her interlocutors unwittingly have contributed to a critical preoccupation with mainstream cinema, and a move away from serious innovation and guidance for feminist filmmaking practice.

In "Visual Pleasure" Mulvey takes up the radical critical practice of rereading classical mainstream films to look at the fissures and contradictions that are 'unconsciously' present in all cultural production. To do this she resurrects the type of critical practice put forward by Jean-Luc Comolli and Jean Narboni in the October 1969 issue of Cahiers $d u$ Cinema. They point out, "Clearly, the cinema 'reproduces' reality: this is what a camera and film stock are for -- so says ideology. But the tools and techniques of film-making are a part of 'reality' themselves, and furthermore 'reality' is nothing but an expression of the prevailing ideology"9 . Mulvey adds a feminist twist, arguing that the organizing patriarchal logic of mainstream realist cinema necessarily reproduces classic structuralist binary oppositions: male/female, good/bad, active/passive (men act and women appear). ${ }^{10}$ Within patriarchal cultural reproduction the female character is always cast to the negative, second half of the binary.

Mulvey is, of course, not the first to write using psychoanalytic approaches to film, but her contribution brings in the concept of the (ultimately fetishistic) gaze, the idea of the pleasure in looking. She also develops a theory of how film reproduces ideological

\footnotetext{
${ }^{9}$ Comolli and Narboni.

${ }^{10}$ Erens: 1990: 4.
} 
binaries by constructing female characters as objects to be viewed, whereas male characters are active holders of the gaze. Reworking Lacan's Mirror Stage, she suggests that the cinema screen acts like a mirror that constitutes a three-form gaze, which ultimately privileges male agency. The male viewer either identifies with the male protagonist as his ego ideal, or he participates in the pleasure of the gaze when the camera is trained on the woman. The woman is relegated by Mulvey to be the object to be gazed at.

Mulvey further suggests the subjective use of the camera indicates a male perspective, which is aimed at the male viewer. According to Mulvey film narratives are made by and for men and for their pleasure:

As the spectator identifies with the main male protagonist, he projects his look onto that of his like, his screen surrogate, so that the power of the male protagonist as he controls events coincides with the active power of the erotic look, both giving a satisfying sense of omnipotence. ${ }^{\prime \prime}$

To investigate her point, Mulvey sets up Hitchcock as her theoretical 'straw man', ${ }^{12}$ but in order to do this, she must paradoxically take his films largely at face value. In other words, in order to generate a feminist tactic of re-reading mainstream films against the grain, she must do exactly the opposite with the films she chooses to critique. ${ }^{13}$ Films like Vertigo and Rear Window fit in well with Mulvey's Lacanian psychoanalytic argument. Hitchcock himself was greatly invested in Freudian psychoanalysis, and Mulvey rightly reads many psychoanalytic devices into the films. However, while I would agree with

\footnotetext{
${ }^{11}$ Mulvey, 1990: 30.

${ }^{12}$ She critiques von Stemberg too, but her critique of Hitchcock seems to have 'caught the eye' of most critics.

${ }^{13}$ Why she does this will become clearer in the second half of this essay.
} 
several of Mulvey's arguments regarding Hollywood film, she seems to ignore the fact that Hitchcock was deeply aware of the psychoanalytic aspects of his narratives.

Although she recognizes that Hitchcock "takes fascination with an image through scopophilic eroticism as the subject of the film," ${ }^{14}$ she then fails to acknowledge within her critique how scopic pleasure as a subject could be seen to form an integral part of Hitchcock's own narrative structure. Here her argument becomes a tautology. She argues, for instance, that, "In Vertigo, the subjective camera predominates. Apart from one flashback from Judy's point of view, the narrative is woven around what Scottie sees or fails to see. The audience follows the growth of this erotic obsession and subsequent despair precisely from his point of view." ${ }^{15}$ Mulvey holds this example up for scrutiny as indicative of Hollywood film as a whole, treating Vertigo as though it belonged squarely within, rather than as a critique of, the film noir tradition, where the female character is always enticing, but represents danger, even death (castration) to the male protagonist. ${ }^{16}$

Interestingly, then, Mulvey misses her own point when she notes:

In Vertigo, erotic involvement with the look is disorienting: the spectator's fascination is turned against him as the narrative carries him through and entwines him with the processes that he is himself exercising. The Hitchcock hero here is firmly placed within the symbolic order, in narrative terms. He has all the attributes of the patriarchal superego. Hence the spectator, lulled into a false sense of security by the apparent legality of his surrogate, sees through his look and finds himself exposed as complicit, caught in the moral ambiguity of looking. ${ }^{17}$

\footnotetext{
14 Ibid: 36.

${ }^{15}$ Ibid: 37 .

${ }^{16}$ For a discussion on the femme fatale as excessive femininity see Mary Ann Doane's "Film and the Masquerade: Theorizing the female spectator" in Feminism and Film E. Ann Kaplan ed. (Oxford: Oxford University Press) 2000.pp. 418-36, esp. pp.437-38

${ }^{17}$ Mulvey, 1990: 38.
} 
She does not explore further the structural self-reflexive device here. In her summary, she sees Vertigo on the surface as a regular Hollywood thriller, with typical antifeminist elements. But by associating the (assumed) male viewer with Scottie's deadly fetishist gaze, Mulvey implicitly suggests--but does not recognize--that Hitchcock himself consciously and effectively calls attention to the antifeminist components of the typical Hollywood film noir genre. She condemns Hitchcock's psychological narrative by including his work within in a totalizing rubric of mainstream Hollywood films, and implies that there are extra-textual psychoanalytic explanations that can account for the seeming slippages within the text, rather than recognizing those slippages to be part of Hitchcock's narrative devices, which are meant to instruct the viewer on the normative function of the genres he stylistically parodies in his films.

Mulvey's take on male scopic pleasure creates a double negative effect which excludes the female spectator from any involvement in or enjoyment of the films, and by extension film in general. This conundrum has led earlier reactions to "Visual Pleasure" to centre on female spectatorship, that is, to extending gaze theory toward a female agency. Although, as I will explore later, this exclusion of the female spectator may be useful to a feminist dialectic, the preponderance of responses have tended toward opening up a space in mainstream film for the female viewer.

One of the best-known responses to "Visual Pleasure" is found in Tania Modleski's The Women Who Knew Too Much. Modleski argues that Hitchcock is neither "utterly misogynistic nor... [is he] largely sympathetic to women and their plight in patriarchy, 
but that his work is characterized by a thoroughgoing ambivalence about femininity-which explains why it has been possible for critics to argue with some plausibility on either side of the issue." ${ }^{18}$ Modleski seeks to carve out a type of privilege for Hitchcock's female characters, and from there begins to theorize toward a feminist spectatorship, which realises itself through a strategy of "reading against the grain" of his films. Modleski inverts Mulvey's psychoanalytical take on Hitchcock by re-casting some of his female characters as phallic women.

Where Mulvey's theory completely occludes the woman in the audience, Modleski attempts to create a theory of female spectatorship, which moves toward a subversive feminist re-reading of Hitchcock. She argues, for instance, "In films from Rebecca on, it is more often the mother/daughter relationship that evokes [a] threat to identity and constitutes the main 'problem' of the films." Modleski's take therefore is that it is the female characters which drive Hitchcock's films, not simply because women [don't] represent castration, but because their own attachments to their mothers go unresolved. Therefore female desire in Hitchcock is a 'double desire,' "a desire that is both passive and active, homosexual and heterosexual" ${ }^{19}$ - it is, in other words, a bisexual desire.

Rather than having no scopic pleasure, as Mulvey purports, the female spectator, for Modleski, gains a psychologically invested agency that rivals that of the male viewer. But Modleski also denies any type of subversive narrative structure in Hitchcock.

\footnotetext{
${ }^{18} \mathrm{Ibid}$ (emphasis in the original).

${ }^{19}$ Ibid: 3.
} 
Modleski recognizes how narrative is being manipulated by Hitchcock, but by concentrating too much on the gaze in these films, her argument misses the opportunity to recognize the potentially deconstructive themes present in Hitchcock's films that could be instructional for a radical feminist practice even within mainstream film.

Part of this reaction to Hitchcock has to do with an earlier feminist tendency to reject artists who were considered auteurs-- a topic I will address later in this paper-- so that the psychological aspects of Hitchcock's films have tripped up feminist criticism. There has been a tendency to focus on subversive female agency at the expense of recognizing other potential subversive deconstructive aspects available in his work. The two films Mulvey chooses to focus on are indicative of Hitchcock's awareness of specific cultural phenomena, which were taking place during the 1950s. Wendy Chapman Peek, for instance, investigates an apparent shift in notions of masculinity that was evident when Hitchcock's Rear Window and Vertigo were made during the 1950s. The return of veterans to the US after WWII invoked a set of gender tensions in a culture trying to realign itself to classic divisions of labour. During the war, traditional divisions had had to be done away with, but with the return of a male workforce, they needed to be reintroduced rather abruptly. Economic success was construed to be closely associated with masculine sex appeal, ${ }^{20}$ through a media that played a crucial role in retraining Americans to a gender-based division of labour.

${ }^{20}$ Chapman Peek, 1998: 2. 
Psychoanalysis gained popular interest at this time, and in 1948, with the release of the Kinsey Report (Sexual Behaviour in the Human Male), magazines barraged readers with its findings about male sexual activity along with other juicy popular psychology treatises. The Kinsey report indicated that not only were men more sexually active than had been imagined, but more men were engaging in, or had engaged in, homosexual activity. Heterosexuality could no longer be assumed; it had to be proved. ${ }^{21}$ At this moment, heterosexuality not only had to be more than just acting the part, it required conformity to dominant cultural practice that paradoxically feminized the male, since conformity is ultimately associated with the feminine. ${ }^{22}$ Yet, an excessive masculinity was "derided as 'swagger and swearing and mountain climbing." To be a 'real' man became inherently contradictory. For Chapman Peek, Vertigo expresses anxiety surrounding these perils awaiting men.

According to Chapman Peek's analysis, marriage represented the ultimate double bind for the married man was a feminized man, while rejecting marriage, and therefore exhibiting a hyper-masculinity revealed a type of immaturity. It is in this vertiginous tightrope performance of masculinity, the need to not be too masculine and especially not too feminine, that Chapman Peek detects the source of anxiety for Scottie in Vertigo. For Chapman Peek, through his search for/construction of Madeleine, who embodies a an

\footnotetext{
${ }^{21}$ Ibid: 7.

${ }^{22}$ Ibid: 10 .
} 
ideal '50s model of femininity, "Scottie will be finding [his] own masculinity, so that [she] will act as [a mirror] 'reflecting the figure of man at twice its natural size.",23

This reading is certainly in keeping with the feminist-psychoanalytic arguments stated above, echoing Mulvey's notion of the sadistic male gaze. ${ }^{24}$ Modleski's point is evocative here, as she argues, "What both male and female spectators are likely to see in the mirror of Hitchcock's films are images of ambiguous sexuality that threaten to destabilize the gender identity of protagonists and viewers alike. ${ }^{25}$ For Chapman Peek, the search for the ideal woman reflects the cultural angst of the '50s-era male. It is a search that can only be successful if the woman remains invisible/silent. ${ }^{26}$ Once she is seen/speaks she becomes dangerous, a threat to masculinity itself. In other words, the search for the woman is at once what makes, but inevitably undoes, the man!

But marriage is no less treacherous for the woman. In her essay "Is the gaze male?" E. Ann Kaplan explores the issue of female spectatorship more generally. She notes that women do enjoy Hollywood films, a fact that feminist criticism does not seem ready to acknowledge. The melodrama, for instance, is not simply Hollywood's condescension to female audience requirements. The family melodrama also operates to instruct women on the 'ethical imperatives' of patriarchal society, and this imperative requires the woman to accept her role within marriage and domesticity. Within this society, the woman has a

\footnotetext{
${ }^{23}$ Ibid: 11.

${ }^{24}$ See Mulvey, 1990: 30.

${ }^{25}$ Modleski, 1988: 5.

${ }^{26}$ Chapman Peek, 1998: 12.
} 
specific role to play: "Assigned to the place of object (lack), she is the recipient of male desire, passively appearing rather than acting." ${ }^{27}$ Thus, Kaplan argues, women derive pleasure in identifying with objectification, in the desire to be looked at. ${ }^{28}$ In her wish to be a "good girl," then, the female spectator is interpellated by these films into the reification of feminine domesticity. ${ }^{29}$

Marriage in Hitchcock articulates a double bind for women as well. As Kaplan suggests, the implied desire of women in the melodrama is to get her man, and the heterosexual female spectator often identifies with this desire. Yet, marriage, in Western culture, has proven to be a repressive institution for women, since property has historically been passed through the woman from her father to her husband. Indeed, Elster's relationship with Madeleine in Vertigo reveals yet another aspect to the narrative trajectory of marriage. Elster's wealth has been acquired through marriage to Madeleine, whom he ultimately destroys, suggesting that in this system once property has passed through the woman, she becomes no longer useful. The values of patriarchal property and conditions of its exchange are expressed in Hitchcock as destructive to women. Marriage in Hitchcock, then, carries an ironic twinge. It is often the complete opposite of closure. ${ }^{30}$

\footnotetext{
${ }^{27}$ Kaplan, 1983: 26.

${ }^{28}$ For Kaplan, though, simply recognizing the masochistic pleasure of the female spectator is not enough. She calls for a more rigorous psychoanalytic understanding of gendered pleasures and argues for strategies toward changes in discourse.

${ }^{29} \mathrm{Cf}$. Doane in The Desire to Desire: "the woman's film does not provide us with an access to a pure and authentic female subjectivity, much as we might like it to do so" (4). Cited in Dayal, Samir "Inhuman Love: Jane Campion's The Piano", Postmodern Culture - Volume 12, Number 2, January 2002.

${ }^{30}$ This section is based on my essay "[re]viewing the male gaze in Scorsese through Hitchcock."
} 
Because Hitchcock was largely believed to be a misogynist, the very devices he employs to expose the narrative excesses of generic film have been ironically assumed by many film critics to be patriarchal residue in his own films. Mulvey sees him as unwittingly reproducing patriarchal ideology; Modleski sees his ambivalence as destructive, since women are consistently punished in his films. Ultimately, though, none of these writers produces a transgressive theoretical practice since each of their contributions assumes the Oedipal trajectory, which makes up patriarchal culture. Gaze theory alone is insufficient to effect change without an applied practice.

The fact that the politically practical aspect of "Visual Pleasure," written by a woman who is herself a filmmaker, is addressed with less fervour or interest by present day academics is an issue that needs further exploration. The basis for this lack of awareness of the radical characteristics in "Visual Pleasure" is, to my mind, at least two-fold. First, by the time that Modleski and Kaplan and the others were writing, the militant politics that had arisen during Watergate and the Vietnam War were being eroded. The sociopolitical scene had become much more conservative with the advent of Reaganomics. ${ }^{31}$ By the 1980s, much of the fervour and rebellious politics of the ' 70 s had quieted into a "communal sigh of relief, marked initially by the advent of the Carter administration, that anticipated Reaganism and the full restoration of the 'Law of the Father."' ${ }^{32}$ On the other

\footnotetext{
${ }^{31}$ As Wood points out, "Vietnam and Watergate did not undermine confidence merely in a single government, but in the entire dominant ideology, centred upon patriarchal law; the crisis in ideological confidence permeated every level, calling into question the authority, not only of the symbolic fathers (government, President, police, organized religion), but the literal father within the patriarchal nuclear family and of the internalized 'father' installed within us from early childhood, the guarantor of our conformity to the established societal" Wood: 1985: 2.

${ }^{32}$ Ibid.
} 
hand, recalling that by the time "Visual Pleasure" was written feminist critical practice "was firmly institutionalized," the essay also represents a moment of hegemonic inclusion for women's studies. This mixture of institutional power along with a social move to the right led feminist visual cultural theory down some strange roads. The consciousnessraising activities of ' 70 s feminism, which I shall look at in more detail in the next section of this essay, found itself with some bizarre bedfellows, especially when it came to representation politics in pornography. Eerily echoing some of the arguments of the Christian right, radical feminist visual theory became preoccupied with issues of censorship. It was an odd time that saw the likes of Susan Brownmiller berating Hugh Hefner on primetime.

Meanwhile, the academy during this period saw visual cultural theory move away from the sociological and become firmly entrenched in the psychoanalytic. I am by no means the first writer to note an institutional-type power in feminist criticism that has tended to favour psychoanalytic/post-structuralist approaches. However, it may be useful to quickly note some shifts in feminist writers' methodology that had taken place by the mid ' 80 s. Rey Chow locates one such move in feminist literary criticism by Toril Moi, who in 1985 published Sexual/Textual Politics. Moi's book is an effort to introduce a hybrid approach to Anglo-American literary theory that moves beyond the socio-political by introducing the more academic approaches of the French feminist philosophers, like Cixous, Kristeva and Irigiray. 
Here, Chow notes academic snobbery, suggesting, "As an account not simply of varied feminist practices but also of cultural difference, Moi's discussion presents AngloAmerican feminists as heavy-footed country bumpkins who are trapped in their parochial women's worlds... and the French as suave and nimble cosmopolitans because they know how to read. ${ }^{33}$ Although Chow's attitude toward Moi's work is a bit heavy-handed, her essay points to a contemporary frustration with the academic privileging of the psychoanalytic in literary and film criticisms. Moi's privileging of the psychoanalytical/post-structural approach of the French feminists over radical sociosexual politics, such as consciousness-raising, points to a moment when the politics of the signifier replaced activist politics as strategy in feminism's concerns.

Annette Kuhn makes a similar move away from the socio-political in Women's Pictures, but she works to reassert a radical textual critical practice along with examining feminist filmmaking practices to investigate the interconnectedness between feminist film theory and feminist film itself. Like Moi she brings the French psychoanalytic feminists into the mix, postulating, "a cinema which evokes pleasures outside the masculine structures of voyeurism might well set up a 'feminine' approach to cinematic signification. ${ }^{34} \mathrm{Kuhn}$ strategically surveys the theoretical and the production aspects of feminist film theory, embracing both the post-structuralist tactic of reading against the grain as explored above, and then building on this to express what feminist film language might look like, as she sets out to discover precisely what makes a feminist counter-cinema. But in the

\footnotetext{
${ }^{33}$ Chow: $1999,138-39$.

${ }^{34}$ Kuhn: 1980,65 .
} 
final chapter of her book, she recognizes that above all, "questions of textual address, conditions of reception, and suchlike remain rather academic so long as films are not even made, or when they are if the opportunities for exhibiting them remain severely limited." ${ }^{35}$ For Kuhn, ultimately, theory is a poor stand-in for a materialist filmmaking practice. Nonetheless, Kuhn's use of critical theory and post-structuralist discourse, makes her book difficult and dense, making her book more suitable for academic study rather than as any sort of practical guide for the feminist filmmaker.

It may be self-evident to many who work to carve out spaces in academia why a highly complicated feminist philosophy would be championed within a university setting that is nothing if not patriarchal in its constitution. There is a certain inclination to inhabit our hard-fought space within the hierarchal structure of academia by out writing everyone else. Frustration is apparent toward this impulse in B. Ruby Rich's Chick Flicks:

By the mid-eighties, psychoanalytic feminism was consolidating its position as the only cinematic approach to carry weight in the academy. Its opaque language and narrow assumptions were becoming, astonishingly to me, the lingua franca of feminist film theory. I was feeling increasingly isolated and disheartened.... Even worse, those of us who had been committed to grassroots organizing, film activism, and accessible language were spread too thin to turn out books, while those whose academic track required publications were suddenly turning out volumes that not only guaranteed their own job security but significantly advanced the primacy of their approach in the world of film studies. $^{3 \hat{6}}$

The writing, it would seem, has become of more interest to the people writing than to anyone committed to social change. More than being a matter of simple complacency, as mentioned by Melinda Barlow, then, young would-be feminists could be seen to be

\footnotetext{
${ }^{35}$ Ibid: $178-79$.

${ }^{36}$ Rich: 1998, 287.
} 
rejecting this impulse in feminist philosophy and by association rejecting feminism all together. At any rate, the tendency to reject feminism by younger academics suggests that the dominant academic approaches to film theory no longer offer much to today's prospective feminist filmmakers.

When identity politics are added to the mix, things become even more complicated. Jane Gaines, for instance, problematizes the universalizing tendency of psychoanalytic film criticism to "inadvertently reaffirm white middle class norms" when used to explain Black family relations ${ }^{37}$ : "On this point, Black feminists diverge from white feminists as they repeatedly remind us that Black women do not necessarily see the Black male as patriarchal antagonist but feel instead that their racial oppression is 'shared' with men." ${ }^{38}$ Rey Chow, in "When Whiteness Feminizes...: Some consequences of a Supplementary Logic," points out how white feminist theory, in its polemic rejection of the male-centred gaze, is still unable to transcend the racial other. These examples stress how complicated looking and representation are for women of colour, while Gaines' contribution to spectator theory also marks an attempt to realign the socio-political into feminist critical theory.

Terry Eagleton has argued that the move to a political engagement of reading against the grain and an excessive interest in representation is indicative of a retreat in Left politics into a glamorized politicization of discourse itself. For Eagleton, this shift from radical

\footnotetext{
"37 Gaines: 1990b, 198.

${ }^{38}$ Ibid.: 202
} 
militant resistance to a radical academic resistance reveals a deeper political failure of the Left to bring about a meaningful end to class oppression. ${ }^{39}$ But Marxist theory, with its privileging of labour, also has had a tendency to be blind to the experience of erasure of women and people of colour. Even within radical Marxist groups, there are anecdotal stories of collective tasks being allocated along traditional divisions of labour--for instance, women doing the typing; men doing the picketing.

With this in mind, "Visual Pleasure's" tactic of precluding the female viewer from any scopic pleasure in mainstream films is a clever one. While reactions to the essay have gone off-track, it is imperative to recognize that Mulvey is really opening up a space for women filmmakers, and her essay could be read as a treatise of how to avoid reproducing patriarchal ideology. When Mulvey wrote "Visual Pleasure," although she was an active filmmaker and had some sway in the avant-garde film circuit of the '70s, women filmmakers were still experiencing sexism from their male counterparts despite these male filmmakers' anti-ideological aspirations.

Certainly, most of the 'great' thinkers within film criticism were male, and Cahiers $d u$ Cinema, with its editorial creation of the theory of the auteur, ${ }^{40}$ unwittingly lauded the male director's genius--hence the all out rejection by early feminist film critics of Hitchcock, who was among those considered auteurs. From a feminist perspective, theories of the auteur did little to redeem mainstream film, or avant-garde film for that

\footnotetext{
${ }^{39}$ Eagleton, 1996: 1-19

${ }^{40}$ see especially Peter Wollen's "The Auteur Theory" in Signs and Meaning in the Cinema, 1972.
} 
matter. Avant-garde filmmaking may have worn the mantle of political anti-ideology, but women were clearly seen to be useful only on screen, with their clothes off. This is a brutal example of how socialist politics, without the input of identity politics is unable on its own to transcend all forms of oppression.

Ruby Rich paints a vivid picture in an essay entitled, "A Woman's declaration of

Secession from the Avant-Garde":

It wasn't only leftie politicos that thought a woman's place was on her back: these avant-garde artists, whose politics were often closer to royalist than anything else, thought the same (or, in their case, on her back and on camera). Imagine the seventies: a chosen circle of guys elevated as gods for their cutting-edge work, the deification of structuralism as the only genuine way to make films, a total absence of women filmmakers in any pantheon, and a determinedly uncritical attitude toward representation of women on celluloid" ${ }^{4 !}$.

From this point of view, it's clear why Mulvey might suggest that films made by men cannot go beyond patriarchal representation. But in so doing, she sets off a theoretical conundrum that at best realizes itself through in-fighting over what constitutes a feminist aesthetic, and at worst recapitulates feminism into biological determinism.

Mulvey is asserting in "Visual Pleasure" the beginnings of a discussion of the types of films women should be making. However, where philosophical feminist film criticism may have been co-opted by psychoanalytic approaches, the theory of what kinds of films feminist filmmakers ought to make has proved to be just as contested. Mulvey's approach in "Visual Pleasure" is to put forward an methodology, which still makes use of avantgarde techniques, while being aware of the material conditions of filmmaking:

\footnotetext{
${ }^{41}$ Rich: 1998, 104.
} 
Cinema has changed over the last few decades. It is no longer the monolithic system based on large capital investment exemplified at its best by Hollywood in the 1930s, 1940s, and 1950s. Technological advances (16mm, etc.) have changed the economic conditions of cinematic production, which can now be artisanal as well as capitalist. Thus it has been possible for an alternative cinema to develop. ${ }^{42}$

Mulvey here recognizes a material/economic opportunity that could generate a feminist discursive opening within the world of capitalist image production, an opening that could potentially provide, women especially, access to a means of image production that had not been available previously. Where mainstream film is monologic in her construction of it, Mulvey manoeuvres toward a dialogic opportunity for woman's voice. However, she does not develop what this woman's 'voice' might look like, and does not address the issues of women's engagement with technology and problems of distribution.

The learning curve that women must go through truly to gain practical access to the equipment is a dilemma still faced by would-be women filmmakers. Technology continues to be threatening to women despite constant reassurances that new imagemaking technologies open up spaces for women to create a language of their own. In a recent video shooting course I took through Women in Film and Television (WIFT), I came face to face with women's fears of technology. While there were three men in the course who were practically tossing the cameras to each other, the ten women enrolled in the course approached the camera the way we joke a man approaches a newborn. Of course, one of the main points of this particular class is to help women overcome this trepidation. That this is still how women approach cameras only heightens the fact that

\footnotetext{
${ }^{42}$ Mulvey: 1990, 29.
} 
this huge learning curve has functioned to keep women out of even counter-image making distribution circuits, their work often being seen (by themselves or by a set of standards arrived at largely by male artists) as naive or unskilled. ${ }^{43}$ If the notion of the auteur filmmaker is a foreign one for the woman filmmaker, her nascent engagement with technology makes aesthetic arguments doubly alien. It is impossible to even worry about form and content when just learning "how" to point the camera is a dilemma.

Melinda Barlow illustrates this chronic situation:

At present in the Film Studies Program at the University of Colorado, Boulder, where I teach, there are 553 majors. In the senior class in filmmaking production, of which there are three sections, each capped at 15 students, there are usually only one to two female students per class. This number is lower than it was when I arrived in 1996, when there were on average four or five women per advanced class in film production (hardly a majority, but higher than the current figures. When I informally surveyed my female students as well as male and female colleagues who teach filmmaking at $\mathrm{CU}$ at to why this might be the case, they cited several all-too-familiar reasons: filmmaking seems to be an exclusively male domain; the male students are proprietary if not on occasion "superior" about their knowledge about and ease with the equipment; and women therefore often feel self-conscious and fearful about learning how to operate it in their presence. $^{44}$

Clearly, given the statistics stated at the opening of this essay, what a woman's film looks like will cease to be relevant if this issue isn't rectified, because there will no longer be any significant films to look at anyway.

This dearth of technological expertise among would-be women filmmakers has been seen as an opportunity, especially in the area of video. Jody Berland in "Video-Language -

\footnotetext{
${ }^{43}$ For a more in-depth discussion see Lauren Bergstrom's discussion in Penley and Bergstrom: 1985, 29299.

${ }^{44}$ Barlow: 2003, 25.
} 
The Common/place" suggests that the idea of simply picking up a video camera is empowering. For Berland, although film and now television have evolved languages of their own, video still has not developed a language, and so those of us who pick up the camera participate in the creating of a new idiom. For these reasons, perhaps, it is the ideal medium for feminist filmmakers to invest in. Peggy Gale adds in "Video has captured our Imagination" that unedited home video exists in a multitude of homes sitting in contradistinction to the highly edited and slick product of broadcast television. She suggests that when the feminist artist turns the camera on herself, she is enacting the desire to capture herself in history. Certainly the chance to be part of creating a language is pertinent for the feminist image-maker, but video so closely resembles broadcast television, since it is usually exhibited through a TV, that viewer response is conflated with responses to television. In addition, consumer editing and software manuals "teach" or suggest accepted editing rules. The widespread availability of this type of software and equipment does allow anyone to pick up a camera, but it is at the risk of video language simply being capitulated into the dominant broadcast language.

By singling out video production as a prospective feminist practice, Berland opens up a potentially radical space in feminist visual cultural production, because video is not typically driven by consumerism. Therefore the camera eye does not always have to appeal to widespread audiences. This lauding of the possibilities for feminist production in video is useful because it allows for a naïve condition at the moment in video production. Women are not necessarily so far behind men, then, because video language itself has not been expressed. But does a woman by simply picking up the camera 
necessarily invoke a feminine language? And must this language therefore remain naïve, nascent, liminal? Gale's celebration of the imperfect home video might suggest this. But this approach would necessarily relegate woman's visual production to the amateur in contrast to the more slick counter-cinema found in avant-garde films. Furthermore, does a feminine sensibility necessarily connote a feminist one?

The accessibility offered by the $16 \mathrm{~mm}$ camera mentioned by Mulvey was already being taken advantage of in the US during the postwar years by avant-garde filmmakers, ${ }^{45}$ and engendered a radical theoretical space that hailed back to interwar/post Soviet revolution years. ${ }^{46}$ This alternative cinema is a cinema that aims at subverting the illusion of reality created in dominant cinemas and engages in practices to deny the objectivity of the camera. To '70s feminist (especially British) filmmakers like Mulvey, the avant-garde film aesthetic offered a formal space to experiment with post-structuralist and psychoanalytic issues in relation to feminist theory.

Avant-garde film seeks to produce "conscious spectators" that comprehend the necessary fictiveness inherent in all film. ${ }^{47}$ For (post) structuralist theorists, for example, dominant film practices operate to hide their own materiality, creating an apparently seamless cohesiveness in the projection of reality within the narrative. The aim of realist cinema is to create an illusion that the spectator is listening in on or witnessing a real event. Therefore, realist cinema is reactionary in a political sense because it cloaks its own

\footnotetext{
${ }^{45}$ Rabinovitz; : 1991, 43.

${ }^{46}$ Buchsbaum: 1990, 126.

${ }^{47}$ Penley: 1985,585 .
} 
constructed nature, while the interests of the dominant ideology are naturalised within the diegesis of the illusory fantasy world. An avant-garde film practice works to wake up the spectator by calling attention to its own constructedness. In this sense, avant-garde cinema is seen to reject the idea of the disinterested camera, which ostensibly reflects life back to the viewer as unmediated reality. Feminist theory develops this idea by recognizing that gender differences that are depicted as reflections of the naturalised world in the cinematic world are nothing more than constructions themselves.

The advent of newer, cheaper, lighter equipment is also not new to feminist concerns. Maya Deren, for instance, was one filmmaker who took advantage of the postwar availability of the lighter $16 \mathrm{~mm}$ camera equipment during the 1940s. Although she rejected the notion she held adherence to any aesthetic camp, especially surrealism, Deren's contribution to the American avant-garde circuit is one feminists have been inclined to take up as their own: "Long before Claire Johnston called for a women's counter-cinema that would rewrite patriarchal film language, Deren asserted an oppositional voice to Hollywood cinema and confronted Hollywood's formal aesthetics as a set of political practices." ${ }^{48}$ Her work could be said to typify the kind of 'feminine' cinematic language that has concerned feminist filmmakers and theorists for years.

Reading Meshes of the Afternoon and At Land, Rabinovitz argues, for instance, "Deren's recurring use of multiple selves suggests that an examination of plural identities is not so much a schizophrenic disorder or psychoanalytic interpretation as a radically original

\footnotetext{
${ }^{48}$ Rabinovitz: $1991,9$.
} 
means toward self-discovery. This approach, in fact, abounds in women's writing." ${ }^{49}$

Rabinovitz is clearly influenced by gaze theory in her assessment of the

Deren/protagonist in Meshes and At Land:

\begin{abstract}
Shots are constructed around her acts of looking, but what she sees follows no conventional rules of physical stability since the objects, people, and environments frequently become transformed into something else. What is constant are both her ongoing presence and controlling gaze--even if it cannot control the stability of the world around her. In relation to the protagonist's construction as the film's subject, the spectator also watches her framed as a central object for being looked at.... Once again, the terms of subjectivity Deren engages are ambivalently inscribed in relation to patriarchal representation of women. ${ }^{50}$
\end{abstract}

Although Rabinovitz is not claiming that women are inherently feminist when they take up the camera, her description of Deren's outright rejection of categorization coupled with Rabinovitz's subsequent feminist reading of Deren's films generates a sense that there is something essentially feminine when women thoughtfully make art. At the very least, perhaps the imagistic language of metaphor and juxtaposition is a link toward the elusive feminine cinematic language.

Deren had a sophisticated understanding of semiotics and her films express her attempt to move cinematic language toward the imagistic to "break from Hollywood mimesis." Avant-garde theory in the hands of a woman, it would seem, engenders a feminist film practice, an idea that resonates in Helene Cixous' writing. For a writer like Cixous, by means of Derridean theory, the absent signifier always comes back to the male/female binary, and therefore it is impossible in patriarchal discourse to escape the metaphysical idea of Woman. Language itself creates her. Cixous argues instead for a new language,

\footnotetext{
${ }^{49}$ Rabinovitz: 1991, 66.

${ }^{50}$ Ibid.

st Ibid: 75 .
} 
an écriture féminine. In her essay "The Laugh of the Medusa," she writes "as a woman, toward women," and is speaking of woman's "inevitable struggle against conventional man; and of a universal woman subject who must bring women to their senses and to their meaning in history. ${ }^{.52}$ Cixous is encouraging women to "write their bodies," their experiences. She argues that the Mind/Body binary is equal to the Male/Female. Rather than simply deconstruct the seeming natural in these binaries, she contends that feminine writers need to flip that binary, celebrate the phenomenological. The feminine experience, through her body, is lush and full of creative vegetation; whereas, male rationality is cold and sterile.

There is a certain lure to the idea of privileging the female experience. But as many feminists point out, the privileging of the female over the male does not overturn the essentialist deterministic biologism that has tended to relegate women to the passive side of the binary. Nor does this approach question whether this essentialized female is indeed biologically or culturally constructed. Arguing that by simply giving a woman a camera means that she will make feminist--or at least feminine--films is problematic, because it suggests that women inhabit an inherent femaleness that then is translated through the camera. The trouble, of course, is that the celebration of feminine traits does nothing to confront the social and discursive conditions that create the "feminine" in the first place. Celebration of the feminine does little to challenge the assumptions of a patriarchal order.

${ }^{52}$ Cixous, 1993: 334. 
As well, whether women are essentially more apt to make feminist films simply because they are women or whether "there is a feminine aesthetic or a specific language of women's cinema" has plagued feminist aesthetics inquiries. Teresa de Lauretis warns, to ask women's films to provide formal aesthetic indicators "is to remain caught in the master's house and there... to legitimate the hidden agendas of a culture we badly need change." ${ }^{53}$ Simply creating cinema that 'moves beyond the modes of expression privileged in patriarchal ideology' does not necessarily produce feminist counter-cinema. Obviously, formal avant-garde filmmaking cannot account for what makes a film feminist, while simply stating that because a woman is behind the camera is no more satisfactory to the feminist palette than is the suggestion that Woman is a biologically determined essence.

In her 1985 essay "Rethinking Women's Cinema" de Lauretis approaches the idea of a feminist aesthetic from a slightly different angle. For de Lauretis, it is whom the film addresses above all other factors that initiates a film into a feminist aesthetic - or deaesthetic as the puts it. For her a film becomes feminist when it is able to address the spectator through a spectrum of subject positions. She offers this definition in contradiction to the liberal 'feminist' films that were being pandered to women during the 1980s, like Silkwood or Places in the Heart. De Lauretis suggests that Lizzie Borden's film Born in Flames is an ideal example of the feminist de-aesthetic, arguing that the film succeeds in the crucial radical feminist understanding "that the female subject is en-

${ }^{53}$ De Lauretis: 1990, 292. 
gendered, constructed and defined in gender across multiple representations of class, race, language, and social relations; and that, therefore, differences among women are differences within women, which is why feminism can exist despite those differences and, as were are just beginning to understand, cannot continue to exist without them"

Through her formulation of a feminist de-aesthetic, de Lauretis sets out to address a number of complaints argued within feminist film criticism. She works toward finding strength in the multiple voices of women from different cultures and backgrounds, while her definition of an anti-aesthetic is an attempt to deal with the problematic notion that women filmmakers by simply picking up a camera, whether using avant-garde or realist forms, will naturally make something akin to feminine films. Ultimately, for de Lauretis, "the emphasis must be shifted away from the artist behind the camera, the gaze, or the text as origin and determination of meaning, toward the wider public sphere of cinema as a social technology: we must develop our understanding of cinema's implication in other modes of cultural representation, and its possibilities of both production and counterproduction of social vision." ${ }^{.55}$

She is introducing a potentially radical concept here, shifting the discussion away from metaphysics into the lived experience of our interaction with visual cultures. But her suggestion that we not worry about who is behind the camera takes her argument once more away from the experiential and radical possibilities of the camera, back into a

\footnotetext{
${ }^{54}$ Ibid: 1990,300 , emphasis in the original.

${ }^{55}$ Ibid: 295.
} 
disconnected philosophy. It may be rhetorically ideal to deny a universal feminine quality to women-made films, but strategically, this position does nothing to address the lack of women filmmakers in the first place.

Diana Fuss points out in Essentially Speaking, although 'essentialism' is seen as fundamentally negative, the very codes of anti-essentialism in no way have been problematized. For Fuss, the theorist who argues against determinism often falls into the very trap of metaphysics from which she is trying to free herself, since essence becomes in the formulation "always already knowable." She makes a case instead for a strategic use of essence, suggesting, "that the political investments of the sign 'essence' are predicated on the subject's complex positioning in a particular social field, and that the appraisal of this investment depends not on any interior values intrinsic to the sign itself but rather on the shifting and determinative discursive relations which produced it." 56 Fuss is calling for a calculated risk of 'essence' in feminist writing, a risk that sees a subject occupying contradictory subject positions at the same time. As Rabinovitz points out above, this is a strategy that abounds in women's writing.

De Lauretis' analysis is an important one, because she moves the burden regarding elitist artistic formalism off the shoulders of would-be feminist filmmakers. But she jumps the gun when says that whether a woman is behind the camera is of little concern. All discussion of what makes a film feminist becomes moot if only men, even sympathetic men, have access to that technology. To say that a woman picking up a camera is a

\footnotetext{
${ }^{56}$ Fuss, 1989: 20.
} 
political act is not to simply fall victim to biological determinism. Rather, it is to say that the discursively constructed female subject will express herself in a certain way. In order to effect change in the linguistic realm, women must be able to lend their multitude of voices realised through a whole host of experiences to a dialogic model, which re-visits, re-creates and creates in response to mainstream as well as radical filmic texts.

Given the hurdles women filmmakers have faced, it may be no wonder that those who have trod into the field have found a home in documentary filmmaking. It is through turning the camera on themselves that many feminist filmmakers have "risked essence," either consciously or unconsciously. In her 1978 essay, "The Political Aesthetic of the Feminist Documentary Film," Julia Lesage presents documentary-style filmmaking as an obvious strategic starting point for women filmmakers. Related to a tradition of consciousness-raising documentaries with links to a rich US worker's movement, she critiques a counter-cinema of sorts that addresses the issue of content over form in radical documentaries. For Lesage, the cinema vérité style not only lends itself to use by less experienced hands, but also allows women to speak in their own voices without mediation. For novice women filmmakers in the late 1960 s, the cinema vérité style "not only demanded less mastery of the medium than Hollywood or experimental film, but also offered the very documentary recording of women's real environments. Their stories immediately established and valorized a new order of cinematic iconography, connotations, and a range of subject matter in the portrayal of women's lives. ${ }^{\text {57 }}$ This

\footnotetext{
${ }^{37}$ Lesage: $1990,229$.
} 
assertion backs up Berland's argument that video equipment enables a feminine intervention into visual language.

But the implied unmediated "reality" of documentary film practices inevitably opens up other epistemological issues. This form of filmmaking, for instance, does not necessarily disrupt the myth of the disinterested, non-intentional camera. In his essay "Documentary Film and the Avant-Garde," Bill Nichols suggests a closer relationship exists between avant-garde film and documentary than has been previously accepted: "The appearance of documentary involves the combination of three preexisting elements--photographic realism, narrative structure, and modernist fragmentation--along with a new emphasis on the rhetoric of social persuasion. ${ }^{58}$ Form and content of the documentary tends equally toward an artistic bent, distinguishing it from simple newsreels.

More recently, Alexandra Juhasz has pointed out that documentary films have a history of a victim-documentary tradition, in which the omnipotent, omniscient camera is focussed on the suffering of its subjects, often using first-person testimonial. "Thus the ultimate position of authority for documentarian and viewer is one of judge who determines if the other's suffering is deserved. During this trial, her torment (deserved or not) is re-enacted through the form's reliance upon testimony -- which requires that she relive her suffering--and, arguably, through the victim documentary's very structure. ${ }^{59}$

\footnotetext{
${ }^{58}$ Nichols: 2001, 582.

59 Juhasz: 2003, 78
} 
Writing in 2003, Juhasz still finds herself working to transcend some of the problems inherent in traditional documentary. She too looks back to early feminist documentary filmmaking to inform her own approach to making documentaries about female inmates in America. For Juhasz, the feminist approaches broached by early documentary filmmakers are still pertinent today, because "what makes feminist collaborative documentary unique is that the linking of politics, method, and theory defines and indeed created the field: it is foundational not ancillary.... Collaboration is the obvious and ubiquitous alternative to victimhood." ${ }^{60}$ Representation is still an issue in documentary, but subordinate to expression of experience and unmediated reflection. Juhasz finds much in Lesage's appreciation of the naïve style of "feminist documentary's subjects and theorists [who] begin with a self who is herself, in many ways, like an object, a thing that is not already necessarily empowered. They ask us to consider what feminists have more vehemently flagged about narrative traditions: how bad it feels to be made via representation into the object of another's psychosexual impulses." ${ }^{61}$

Women are better represented in documentary filmmaking circles than in mainstream and even experimental filmmaking, which are still dominated by male "masters," perhaps because the socio-political heritage of feminist consciousness-raising activities has been necessary for women to break into any type of film practice. As a feminist practice, the documentary offers a more straightforward inroad into a filmic institution that has been dominated by strict formal aesthetics. Documentary tenders a forum for divergent voices

\footnotetext{
${ }^{60}$ ibid: 74 .

${ }^{61}$ Ibid: 80.
} 
in a way that avant-garde film has not been seen proffer by feminist practitioners. As well, easier access to low cost video equipment and a freer expressive form has realized more openings for women documentary filmmakers.

At the same time, feminist academics have gained credence through the opaque writing of psycholinguistic approaches to film criticism that abounds in the university. The academic norm of psychoanalytic writing seems intrinsically linked to the avant-garde, with its difficult discourse and elitist aesthetic. ${ }^{62}$ It may indeed be the case that the best opening for women's voices is to be found through documentary filmmaking, but must women languish in, what could be seen, as a simplistic world of consciousness raising that requires women to remain both victim and on the margins? Must the feminine voice eschew any connection to sophisticated formal film language, concentrating, rather on autobiography?

To further investigate this question of feminine and/or feminist language, I'll move on to look at films made by women. First a close look at two films that are integral parts of the feminist film canon. Unlike those of the mainstream canon, which contain masters like Hitchcock, Hawkes, Penn, and also Godard and Truffaut, these are films that are rarely seen outside an academic setting. Still as budding filmmakers (usually male) look to the likes of Hitchcock or Godard to inform their own approaches film, I believe looking back

\footnotetext{
${ }^{62}$ Rey Chow links this to the predominance of white feminism in academia, which has been "reluctant to dislodge white women from their preferred status as the representatives of alterity throughout Western history". She argues: "This racialist reluctance to give up the hold on victimhood is what Nancy Armstrong... refers to as the lingering power of the discourse of captivity."
} 
to Sara Gomez's One Way or Another or Sally Potter's Thriller is a first step toward restructuring a theory toward a feminist filmmaking practice. Both films appeared in North America around the same time (although Gomez's film had been shot earlier; release being delayed due to her untimely death), and both could be seen as exemplifying a critical moment in radical feminist film criticism, a moment where feminists were juggling the implications of structuralist, Marxist and psychoanalytical theories that I have looked at above.

The films appeared just after Christine Gledhill, in 1978, pondered:

\begin{abstract}
We are clearly in a very weak political position if rupturing the place of the subject in representation is our chief point of entry. There clearly is a danger in posing the question in chicken-and-egg terms. But the problem remains if we are to locate an effective point of Feminist attack; how are the socio-economic structures of power and subordination articulated with the repression of femininity in the psycholinguistic construction of the subject? and how can one level effect changes in the other? ${ }^{63}$
\end{abstract}

As these questions still largely go unanswered, or worse, ignored, revisiting Thriller and One Way or Another may serve to address dormant theoretical questions that continue to interest contemporary feminists, who find themselves caught in a theoretical bind, left, after 30 years of debate, with a strategy that focuses its interest largely on reading mainstream film, rather than providing a paradigm, or paradigms, to guide women toward producing their own stories, which are able to occupy both the theoretical and the sociopolitical.

\footnotetext{
${ }^{63}$ Gledhill: 1985,844
} 
To reiterate, for de Lauretis, feminist filmmaking cannot simply concern itself with representational issues: "The idea that a film may address the spectator as female, rather than portray women positively or negatively, seems very important to me in the critical endeavor to characterize women's cinema as a cinema for, not only by, women." ${ }^{64}$ Sally Potter's Thriller speaks to this concern for a cinema that addresses a female audience by wresting the passive female heroine from Puccini's La Boheme and re-writing her, giving her an active voice that ostensibly addresses the female spectator, and does this using an avant-garde aesthetic that is reminiscent of Deren. Meanwhile, Sara Gomez's One Way or Another addresses some of the concerns facing feminist filmmakers, documentary or narrative, by marrying the two forms together.

Strictly speaking, within de Lauretis' formula for defining a feminist de-aesthetic, Gomez's film does not fit that easily. But Gomez is linked to Deren also because their works, while not necessarily purporting a feminist aesthetic contain a certain sensibility that feminists recognize as their own. To be sure, One Way or Another is not an ostensibly feminist film. It is a film that rather takes up the post-revolutionary Cuban film schema of the imperfect film, and falls squarely within in the dominant socialist agenda of the government funded films produced during the $1970 \mathrm{~s} .{ }^{65}$ Yet, Gomez also brings a unique perspective to her film that reflects her marginalized, black, female experience. Through an examination of these two films something approaching that je ne sais quoi

\footnotetext{
${ }^{64}$ de Lauretis: 1990, 296; emphasis in the original.

65 "De cierta manera, by Sara Gomez, is not a film about the condition of women. It is about marginality in Cuban Society during the revolution. While it conveys a particular feminine point of view, it does not have an explicit didacticism" (Humberto Solas in Martin and Paddington, 2001: 12).
} 
that defines the elusive feminine sensibility in feminist films may become clearer. Both Thriller and One Way or Another are interesting to this discussion because they provide examples of a hybridity of filmmaking practices that may or may not be the result of a "natural" female sensibility, and could arguably be said to self-consciously represent the inconsistencies and paradoxes that women filmmakers face when they consciously set out to make radical cinema. As such, these films represent just two of the many spaces offered by divergent feminist film discourses. At the very least, both films represent examples of the power of bringing to the screen the lived experiences of women in patriarchal society.

A product of the Cuban Film Institute (ICAIC), Sara Gomez made films that "were--as imperfect cinema requires--socially and politically functional. ${ }^{66}$ In One Way or Another, Gomez expresses an imperfect cinema through a deconstruction device, which, on a most obvious level, is immediately apparent in its structure. Two aesthetics work together in the film to tell its story. On one level the film is a documentary, which lays out the issues and challenges facing the marginales of Cuban society after the revolution. Built into this is a fictive love story of Yolanda and Mario who represent different aspects of the revolution and different levels of political consciousness. The narrative and documentary forms merge and intersperse throughout the film with apparent abandon, producing an intermingling of structures that serves to highlight the problems facing the revolution. The fictive narrative is affected by the real conditions of the real-life people the main

\footnotetext{
${ }^{66}$ Chanan: 1985,284
} 
characters interact with, and this dichotomy operates to emphasize the contradictions faced by the lived experience of the non-fictive characters.

This intermingling of non-professional and professional actors in One Way or Another is just one way that Gomez uses Brechtian-type distanciation elements within the built-in structural instability of the film. Real-life characters invade the narrative diegesis, taking part in the narrative with all their performance inconsistencies. In other cases distanciation is created through the juxtaposition of documentary episodes to narrative scenes, ${ }^{67}$ and which are sometimes spliced into the middle of those narrative scenes. Thus One Way or Another calls attention to the constructed aspect of documentaries through the untrained performances of real-life "characters" as they play out a kind of mimesis in the narrative sections of the film. Rather than being simply authoritative, the documentary is presented as equally constructed as the narrative sections, and thus the film addresses, in a deceptively simple manner, many of the issues discussed above facing radical and feminist film practices.

Sally Potter's Thriller is also a seemingly simple film. At first reading, it could be seen as a straightforward artistic reiteration of "Visual Pleasure." But Thriller is a complexly constructed film that operates, like One Way or Another, through both its form and content. Where One Way or Another marries two realist forms together, the documentary and the melodrama, Thriller uses many of the techniques found in avant-garde films. Still

${ }^{67}$ Kuhn: $1986,163$. 
both films, although using different forms, utilize often-similar devices, such as deconstruction to tell their stories.

\begin{abstract}
The intended consequence of these deconstructive strategies is to open up space for active intervention on the part of spectators in the meaning production process, to subvert the completion and closure of meaning proposed by dominant cinema, and thus to offer spectators the opportunity to consider their positions on the issues at hand through their own processes of active reading, questioning and discussion. ${ }^{68}$
\end{abstract}

Thriller offers yet another example of feminist tactical deconstruction, and like One Way or Another, employs Brechtian distanciation devices. The "action" of this film seems to take place outside of time or space in a room that looks like an empty attic or garret. Indeed, the movie begins in blackness, beginning with only strains of Rodolfo from Puccini's La Boheme lamenting the death of Mimi. The black screen is disorienting because it lasts for an excruciatingly long time, even leading one to wonder if there is something 'wrong' with the film. It is a bewildering space that is no one space at all, as what would seem to be an eventual establishing shot of the space, is in fact a production still of the set where an actual production of La Boheme played. The "action" in Thriller takes place in a squatters' flat that Sally Potter was living in at the time of filming, an extratextual juxtaposing of Potter's own experience with the romanticized theatre.

In this room outside of space, nothing is seen through the windows or door that lead into it except darkness, recalling perhaps an Absurdist world which immediately links the visual to a formal sense of loss and searching, ${ }^{69}$ as well as providing a potential visual

\footnotetext{
${ }^{68}$ Ibid: 166.

${ }^{69}$ Cf. Martin Esslin's The Theatre of the Absurd (Penguin Books: London and NY, 1980) pp. 299-300. Esslin suggests that the Theatre of the Absurd is an expression of a search to "confront a universe deprived of what was once its centre
} 
metaphor for psycholinguistic theor. Through stop-motion photography and its selfreflexive use of intertextual music-the suspenseful sting from Bemard Hermann's score for Psycho repeats throughout the film and is often interspersed with happicr strands of La Boheme-the film calls attention to itself as construction. The music sting works to connect the film to the thriller genre, and aiso alludes to the deconstructionist format of Hitchcock's work, where nothing is ever as it appears on the surface. It is the ultimate feminine reinterpretation of Hitcheock. This intertextual connection is further expressed, through her use of German expressionistic lighting along with the film's set, connecting the "plot" to Hitchcockian thrillers as well as film noir. These elements combine to deconstruct, as well as in B. Ruby Rich's words, ${ }^{70}$ reconstruct the scene of a crime - the crime scene being the classical bourgeois theatre stage.

But the discussion above regarding Hitchcock becomes even more important to feminist exegesis here because, again, the psychoanalytic makes up the content of the film, but it is surely not the point of the film to reassert some necessary Oedipal arc onto the fimale experience. While the form of Thriller may be connected to the avant-garde, it is a tenuous, ironic connection, where the structure ultimately becomes the content. On one level, the 'plot', literally investigates how female characters are themselves constructcd in classical theatre as not only the locus of male visual/libidinal desire, but as catalysts for male characters' heroism. Through Mimi's questioning disembodied voice, the vicwer

and its living purpose.... It bravely faces up to the fact that for those to whom the world has lost its central explanation and meaning, it is no longer possible to accept art forms still based on the continuation of standards and concepts that have lost their validity; that is. the possibility of knowing the laws of conduct and ultimate values, as deducible from a firm foundation of revealed certainty about the purpose of man in the universe."

${ }^{70}(1998,228)$ 
comes to an intellectual realisation of the "timeless", "essential," Oedipal narrative's necessity to destroy the woman in order for the text to generate a satisfactory pathos through the male hero's experience.

Both Mulvey's and Modleski's takes on the classic narrative form seem to ring true here. But part of the point of Potter's film is to question all the theories that bind women philosophically and aesthetically to a patriarchal trajectory. Outside of time and space, the Oedipal trajectory is no longer necessarily an a priori proposition. A straightforward psychoanalytic reading of this film would miss the point of the film entirely. Therefore, E. Anne Kaplan's assertion that "Mimi I, as female subject investigating herself as object, understands that before she can begin her task, she has to return to the mirror phase: she needs to understand how her subjectivity was constituted and deal with herself as split subject in a symbolic order dominated by the Father" ${ }^{71}$ is not exactly correct. For the multiple voices of Mimi are not searching for classic closure, and their desires sit outside of prevailing theories.

The transcendental "Mimi" appears in three forms within the film: as a Mimi depicted in production stills from an actual performance, which are accompanied by that performer's voice through audio clips which go along with the stills; in the [dis]embodied filmic presence played by French actor Collette Lafont; and as Mimi/Lafont's alter ego played by Rose English who never speaks and represents both Mimi and Musetta -- perhaps even Everywoman. It is true Mimi/Lafont does indeed continually return to the mirror,

\footnotetext{
${ }^{71}$ Kaplan: $1983,155$.
} 
"waiting for a clue"; however, Thriller is a rejection of tendencies of psychoanalytic approaches to desire in narrative. In fact, rather than searching for an in into the symbolic, where she can dream herself into an imaginary self-actualised subject position, this repetitive sequence throughout the film casts off the notion of an essential female subjectivity.

Mulvey's version of psychoanalytic theory assumes the inevitability of Oedipal desire, creating a type of determinism from which female desire cannot escape, nor can it be addressed in anything but negative terms. Thriller questions this universalizing of the patriarchal myth as the only myth available. So Mimi/Lafont's "waiting at the mirror" can only ever give her one part of her story. As in Deren's Meshes of the Afteroon, she discovers not the illusion of a whole self, but a multiple of selves, which directly contradicts any notion of a return to the Mirror Stage. Against the logic of the patriarchal Symbolic, Mimi/Lafont revels in the discovery of multiple selves. The "Other" reflected back to her fluctuates. At one point, Mimi/Musetta/English looks back as a reflection of "timidity and vulnerability". At another, in a repetition of the "title" sequence, a shot shows Mimi/Lafont turned away from the mirror, and her reflection in the mirror creates a mise-en-abyme, as Mimi/Lafont continues to look into the camera ad infinitum. She covers her mouth almost with childish glee as if having said something naughty. It is an early visual clue that she has transgressed patriarchy by denying psychoanalytic subjectivity. In this re-working of the psychoanalytic, after she discovers her multiple selves, rather than an imaginary whole, she speaks. But she does not speak in platitudes; she speaks in questions. She asks, "Was it me?" 
She must delve deeper, ask more questions. As Mimi/Lafont further investigates, the dialogue becomes more complex. The voice interrogates itself: "how could you let yourself be removed?"

The same voice answers, "You were reading in French..."

"What were you thinking of?"

"I was listening, and I was absent."

"You were carried away, certainly."

As a speaking subject, this Mimi can only come into understanding through repeating questions and ultimately rejecting the mirror along with any other philosophies that distract her from her agenda.

The idea of getting carried away is repeated thematically and literally, as Mimi/Musetta/English gets "carried way" by two male figures. The reverberation of the actor being carried away becomes a visual pun as the subject and the signifier collapse into each other. Over and over again through the second half of the piece, Mimi/Lafont tries, haltingly at first, to read aloud from Tel Quel. As this scene is reiterated and becomes clearer, Mimi/Lafont's voice becomes surer, asking more complex questions: "Was the clue to my death within their texts?" With this question she slyly subverts the power of the theory she has read aloud. It would seem then that theory, structuralist, Marxist, or Freudian, cannot emancipate woman, and so Mimi/English is literally carried away, lost, as Mimi/Lafont gets carried away reading theory, completely unaware of the loss. The idea of any emancipation being achieved through theory alone is further 
ridiculed as Mimi/Lafont closes the book and laughs hysterically. It is a laugh that has echoed throughout the film and suddenly becomes connected to the gleeful image of Mimi/Lafont with her hand over her mouth, looking at the camera straight on, addressing the spectator. Her laugh is heresy against the texts of the seminal theorists.

Ultimately, this image brings to mind Cixous' laughing Medusa: "You only have to look at the Medusa straight on to see her. And she's not deadly. She's beautiful and she's laughing." ${ }^{72}$ It is a visual/aural inversion of the Oedipal myth, rendering that myth meaningless for women in History and Art. The psycho-linguistic Oedipal trajectory becomes not an a priori proposition but an heuristic one. It is after she closes the book and turns away from classical theory, then, that Mimi remembers a crucial clue: "They produce stories to disguise how I must produce their goods," thus linking women's experience to the material operations of capitalism. She realises that bourgeois capitalist society craves a romantic narrative and therefore the woman must always die in order to maintain the ideal woman, young, beautiful, vulnerable. There are certainly psychoanalytic inferences here, but the film remains firmly materialist in spite of its overall rejection of classical theory.

The trajectory of Thriller is to question, read against the grain of the traditional narrative text, and above all not to dissolve into ascetic silence, the seeming logical outcome of semiological/psychoanalytic feminist approaches, for a feminist strategy that constitutes constantly arguing with itself, quibbling over language, is of little threat to the type of

\footnotetext{
${ }^{72}$ Cixous: 1993: 342.
} 
society that creates a La Boheme. The argument of the film is that women must eventually close the book of theory and experiment with her own voice (or camera). At first perhaps haltingly interrogative, but as she gains experience, that voice becomes stronger and more in-depth.

Perhaps it is here Thriller and One Way or Another become linked for feminist critics, for it is the process, rather than a move toward closure, not only a radical distanciation that becomes the story. Julia Lesage's take on One Way or another likens feminist art to transformation "that has at its goal altering our understanding of, making more conscious, and actually transforming the relations between the public and private sphere. Power relations are not directly changed by art, but when the feminist sensibility articulated in contemporary art is tied to a movement for social change, it is the capacity to make criticisms, to recognize oneself for the position one is really in, and to imagine real alternatives that women's art serves. ${ }^{.73}$ For Lesage, clearly, women's unique experience inhabiting the private sphere as it is expressed through all its contradictions when she makes her mark in the public sphere is not biologically determined, but is radically powerful. It is an experience only women can express so that dialectics as an aesthetic form serves feminist purposes well. But in One Way or Another women's experience of the private sphere is only part of her experience.

Lesage further develops her materialist theory that was evident in the discussion of documentary filmmaking looked at above. She describes the concept of dialectics as "a

\footnotetext{
${ }^{73}$ LeSage: $1978,11$.
} 
process or method of theoretical, conceptual thinking which has as its end elucidating its object, the concrete world, in terms of the world's all-sidedness, contradictions, determinations, and necessities. Dialectics explains process and change." ${ }^{74}$ The documentary-narrative style mentioned earlier that Gomez experiments with in One Way or Another is most compelling, then, in the fact that "the style and idiom of the film is subordinate to its purpose, never the other way round. Whenever possible a radical aesthetic is explored, but emerges from within, so that the film can be readily grasped and still communicate on a popular level. ${ }^{.75}$

One Way or Another is dialectical, not simply because it uses juxtaposition or depicts conflict; ${ }^{76}$ it is dialectical because through a complex interaction of these textual devices it aims to transform the consciousness of the viewer, as the characters in the film are transformed by the conflicts and resolutions that they face. The film explores a number of issues facing post-revolutionary Cuba--not the least of interest to feminists being its exploration of the public versus private spheres--including how men and women who were formerly economically marginalized scope out different strategies to interact with these spheres. But the overriding agenda of the film is to show that although institutional intervention is an important aspect of revolutionary $\mathrm{Cuba}$, it is through constant collective discussion that individuals grow and the challenges facing the revolution are overcome. The feminist voice is subsumed within this overriding goal.

\footnotetext{
${ }^{74}$ Ibid.: 2.

${ }^{75}$ Chanan: 1985, 284.

${ }^{76}$ Lesage: $1978,1$.
} 
One of the many reasons that feminists identify One Way or Another as a feminist film is that the principle character is a woman, Yolanda. But unlike the heroic exploits of characters like Rodolfo that Potter explores in Thriller, Yolanda is a very flawed character. These flaws operate in contradistinction to the heroic hubris of traditional narratives, however, and are not written into her character to induce pathos. Yolanda is a teacher from a middle class background who is "doing her part" for the revolution by going to teach in a marginalized district. Here the well-meaning revolutionary must face her own contradictions as her chauvinism against her unruly students and their parents shows through in her reproving attitude. Gomez cleverly aligns Yolanda's attitude toward the parents with the official tone of the institutional/bureaucratic politics that are a part of the revolution, as she carefully constructs a dichotomy between women and men's spheres. Yolanda is seen in the film mostly in relation to her students and their mothers, who instantly become defensive in her presence. Hers is a too-rigid holding to theories of revolutionary education. She rejects the suggestions and reprimands of her fellow teachers as strongly as she rejects Mario's machismo in the subsequent scene, a juxtaposition that highlights how the chauvinism she holds onto is similar to the attitudes held by men through the relic of a macho patriarchal society.

Mario on the other hand, who has lived the experience of marginalization and continues to live by residual codes of machismo, is depicted largely with his male counterparts. Unlike the women in the film, played by non-actors, who tend to be shot in profile, the male non-professional actors who appear in Mario's private scenes are often hamming it 
up to the camera, enjoying a type of agency in their participation in the narrative. Mario, too, is in the process of personal transformation when he is introduced at the beginning of the film. The first scene of this narrative is shown out of context, making it impossible for the spectator to delineate exactly what is going, or even what the conflict is about. At the end of the film, the scene replays, revealing that after much pain, Mario chooses to break the macho code and expose his buddy Humberto's lie about why he took time off from work.

One Way Or Another is not overtly didactic, but it does have lessons to teach. Gomez remains revolutionary Cuba's only female feature filmmaker, and as a black woman she had firsthand experience of the life of the marginales. She is therefore not only interested in issues facing women in the film; she is also sensitive to portray the distrust by the 'marginales' toward any official state representative. Within the narrative portion of the film Yolanda plays this role in the eyes of the parents and students, as she does indeed represent a large part the official tone of the revolution. The distant officiousness of the institutional aspect of the revolution is further highlighted in the documentary portions.

In the English dub of the film, the narrative is played out in Spanish with English subtitles, but the disembodied documentary narrator drones on in English. The sterile and officious voice states with authority how things are, reducing "the marginalized" sections of Cuba to some sort of homogenous problem. The film then cuts to a narrative section where the lives of the marginales are anything but homogenous. A multitude of issues and problems are revealed, from racism to sexism to religious issues that individuals face 
in their everyday lives, outside of the official code of communist Cuba. These are issues that cannot be addressed simply by sterile theoretical formulae. The film seems to be suggesting, however, that through collective discussion and working through problems as they appear, the society will transcend its problems, so that One Way or Another transcends the victim-narrative that is often inherent in this type of documentary.

The socialist society depicted in One Way or Another is a society that needs active, conscious members who participate in collective discussion and activity. It is a society that cannot blindly cling to bureaucratic theory. Transformation has not been only a feminist concern in Cuba, and it was part of the ICAIC's agenda when films were financed. But Gomez brings a sensibility to her film, which is unlike the films made by her male counterparts. It is precisely in the juxtaposition of the male and female worlds, the private and the public, which defines this sensibility. The men in her film experience some self-determination through their workers' council, as does Yolanda through her teachers' collective. While the official voice of the narrator drones on, the heart of the challenges faced by women coping with work and family is written on the faces of the real-life women. The men are afforded the "luxury" of debate, while the women of the film find themselves defending their actions.

Although Yolanda is experiencing the power of self-transformation, she is still unable to allow the mothers this same chance to grow. Class issues are clearly privileged in this film, as middle class Yolanda is at odds with the overriding logic of the film, in that she falls back on institutional/patriarchal approaches to deal with problems. She resists the 
activity of the collective; whereas, Mario, however problematically, decides to participate in the collective activity.

As in Thriller, the understanding that sterile theories can only go so far in emancipatory politics before material action takes place reverberates in One Way or Another. E. Ann Kaplan suggests Thriller has "circular rather than linear" ${ }^{17}$ plot, but this take does not portray the whole picture, since the film does follow a path from not knowing to understanding through questioning. This constant questioning requires revisiting the same issues until they are worked out, but each time the same scene or thought is reviewed, Mimi becomes more aware of how she got into her predicament. More accurately, the plot is gyre-like, a hybridization of the circular and the linear. It is through transformation, through the strategic use of hybridity--of theory, representation, questioning, all these--that emancipation begins to be possible. A similar course of repetition is taken in One Way or Another. At the beginning of the film, the spectator is unclear what is going on, but as the film progresses, understanding sets in. As with the characters, the spectator becomes aware of a change. It is a decidedly phenomenological transformation, not one wrought through metaphysics.

Both Yolanda and Mimi get "carried away" in theory. By relying too heavily on formulae to search for ways of transcending patriarchy/capitalism, they become entwined in a futile search. Rather than being a "circular" plot, Thriller, breaks away from theory but

\footnotetext{
${ }^{77}$ Kaplan: 1983, 161.
} 
does provide a type of closure through transformation, because Mimi does find the meaning of /reason for her death, and she translates that Death into Life by telling her story her way. Gomez ends One Way or Another without a formal resolution, as Mario and Yolanda walk away from each other in the midst of massive reconstruction. Both are set adrift from each other at the end of the film, because neither has been able fully to surmount the issues they are facing. Together they represent a society that is in flux, continuing to learn and grow. As with Thriller, Gomez by simply making the film in a male dominated arena from the perspective of her lived experience as a black woman in Cuba, moves beyond theory.

The fact that two such different films from different countries can be so linked thematically indicates that there is something that can be said about a feminist film language. This language invokes an aesthetic, though, that defies a locked down, formal definition. Rather, this is a language of allusion, hybridity. Themes that resonate throughout hint at the phenomenological. Structural tactics in both films constantly use juxtaposition and contradiction. The feminine experience is one of multiple selves, but in expressing incongruity transformation is possible.

Yet if the idea of transformation is a defining thematic for feminist film, it is a process that has eluded the material world of feminist filmmaking. My first overall introduction to feminist film theory came through Patricia Erens' 1990 anthology, Issues in Feminist Film Criticism. The implied telos of Erens' work hints at a type of reciprocal economy between feminist film criticism and feminist filmmakers. The essays are laid out under 
four headings: "Critical Methodology: Women in Representation"; "Rereading Hollywood films"; "Critical Methodology: Feminist Filmmaking"; and "Assessing Films Directed by Women." A wealth of feminist reception theory, the book seems to promise, will lead to women making their own films, through which new feminist theories and approaches can be forged. But it seems that feminist theory and practice has gotten stuck in the mud. Apart from glorious exceptions like Jane Campion and Sally Potter or even Kathryn Bigelow and Sofia Copolla, a mainstream women's filmmaking landscape has been predominantly barren.

Coming from a multi-disciplinary academic background, it is perplexing to me that women have managed to make significant forays in publishing but not into filmmaking. Obviously, the modes of production (but less distribution) are different, but surely not so much so that women should be completely shut out of the one while being able to make gains in the other. The two schools are definitely closely related, and critical practice in both fields often uses similar tactics, while theorists frequently cross back and forth between the disciplines. Feminist literary theory also has a penchant for difficult psychoanalytic/semiological writing; nevertheless, women do both write literature as well as write about it. Why has this not been so for women filmmakers?

The move to psychoanalytic/semiological approaches to feminist literary and film criticism I have mapped out above shows just how inward turned feminist film theory has come. In the end, I think it is in the actual writing of criticsm itself where literary and film feminisms diverge. For the feminist literary theorist is intrinsically connected to her 
subject: she writes about writing, experiments with style and makes her point not only through rhetoric but often with form. The film theorist, on the other hand, is disconnected from her topic, except in the capacity as viewer. It is no wonder that her response can only ever be reactive and never creative, except metaphysically. In order for feminist film criticism to move forward in the early millennium, rather than simply spinning its wheels, this needs to be rectified through a strategic operation to get women picking up the camera as they did in the ' 70 s.

Melinda Barlow's indication that there is a new direction to go in feminist writing through inscribing the history of women's film collectives, which offer "many possibilities for future research, from the phenomenon of video letters to the histories of all of those now-unknown individuals and collectives who produced tapes we have never heard of, ${ }^{78}$ is definitely a step in the right direction. Potential filmmakers need to take a look back at how women's films have been produced and distributed. Barlow's endeavour, she admits, is a nostalgic one. Still, her reminiscence hits on a truthful note, which resonates through 30 years of radical feminist filmmaking practice: "that putting your hands on the camera is for women an empowering and implicitly feminist act [one which] still has real meaning in the new millennium" ${ }^{79}$.

Taking a fresh look at how feminist filmmakers went about distributing their work is very useful, but it must be more than theoretical nostalgia. This feminist archival work must be

\footnotetext{
${ }^{78}$ Barlow: 2003, 28.

${ }^{79}$ Ibid: 27.
} 
translated forward to be of any strategic use. Filmic foremothers like Gomez and Potter illustrate that it is possible to move beyond theory through filmic practice. And while it is true that quotas and affirmative action are imperfect answers to the problem of underrepresentation in certain fields, within a capitalist society quotas are often the only way we have of keeping tabs on particular industries, while at least partially ensuring that marginal groups won't be left too far behind because their members lack experience or sufficient skills. A quota system that generates a pedagogy that addresses women's hurdles regarding technology is an obvious starting place within film schools.

And before even that, little girls need "cameras of their own" early enough in their lives so that technology is not intimidating, seen naturally as boys' toys. We have enough stories of Lucases, Spielbergs, Howards talking about 'playing' with their first cameras. We need more stories like the one found in an interview by Sally Potter with Scott MacDonald for Camera Obscura:

SP: The primary channel for me has always been cinema. That's where I started as a fourteen-yearold and that's where I still am...

SM: What happened when you were fourteen?

SP: My uncle lent me an $8 \mathrm{~mm}$ camera.... ${ }^{80}$

${ }^{80}$ MacDonald: 1995, 191. 


\section{Bibliography}

Allen, Jeanne. "Looking Through 'Rear Window': Hitchcock's Traps and Lures of Heterosexual Romance" in Female Spectators, E Deidre Pribram ed. (NY and London: Verso) 1992. pp 31-43

Allen, Richard W. "The Aesthetic Experience of Modernity: Benjamin, Adorno, and Contemporary Film Theory" in New German Critique, Issue 40, Winter 1987, pp225-240.

Berland, Jody. "Video-Language-The Common/place" in Video re-View eds. Peggy Gale and Linda Steele. [Art Metropole and V Tape: Toronto, 1996] pp. 126-30.

Barnard, Timothy. "Death is not True: Form and History in Cuban Film" in John King et al, eds., Mediating Two Worlds: Cinematic Encounters in the Americas [BFI: London, 1993] pp. 230-241.

Buchsbaum, Jonathan. "Left Political Filmmaking in the West: The Interwar Years" in Resisting Images: Essays on Cinema and History, Robert Sklar and Charles Musser eds. [Temple University Press, 1990] pp. 126-148.

Chanan, Michael. "One Way Or Another" in The Cuban Image: Cinema and Cultural Politics in Cuba [Indiana University Press: Indiana and Bloomington, 1985] pp. 275-303.

Cherniavsky, Eva. "VISIONARY POLITICS? FEMINIST INTERVENTIONS IN THE CULTURE OF IMAGES " in Feminist Studies Spring2000, Vol. 26 Issue 1, pp.171-197.

Chow, Rey. "When Whiteness Feminizes...: Some Consequences of a Supplementary Logic," in differences: A Journal of Feminist Cultural Studies. 11.3 (1999) 137168.

Comolli, Jean-Louis. "Machines of the Visible" in Film Theory and Criticism, Gerald Mast and Marshall Cohen eds., [Oxford University Press: NY and Oxford, 1985] pp. 741-760.

Comolli, Jean-Louis and Jean Narboni. "Cinema/Ideology/Criticism" originally published in Cahiers du Cinema.

de Lauretis, Teresa. "Rethinking Women's Cinema: Aesthetics and Feminist Theory" in Issues in Feminist Film Criticism, Patricia Erens, ed. [Indiana University Press: 
Indiana and Bloomington, 1990] pp. 288-308.

-.-.-"Desire in Narrative" in Alice Doesn't: Feminism, Semiotics, Cinema [Indiana University Press: Bloomington, 1984) pp. 103-157.

Deren, Maya. "Cinematography: The Creative Use of Reality" in Film Theory and Criticism, Gerald Mast and Marshall Cohen eds., [Oxford University Press: NY and Oxford, 1985] pp. 51-65.

Doane, Mary Ann. "The Voice in the Cinema: The Articulation of Body and Space" in Film Theory and Criticism: Introductory Readings, Leo Braudy and Marshall Cohen eds. [Oxford University Press: NY and Oxford, 1999] pp. 363-375.

."Film and the Masquerade: Theorizing the Female Spectator." in Issues in Feminist Film Criticism, Patricia Erens, ed. [Indiana University Press:

Indiana and Bloomington, 1990]

Eagleton, Terry. The Illusions of Postmodernism. [Oxford: Blackwell Publishers ltd, 1996].

Ebrahim, Haseenah. "Afrocuban Religions in Sara Gomez's One Way or Another and Gloria Rolando's Oggun in The Western Journal of Black Studies, Vol. 22, NO 4, 1998 pp. 239-251.

Erens, Patricia, ed. Issues in Feminist Film Criticism, [Indiana University Press: Indiana and Bloomington, 1990].

Foucault, Michel. "The History of Sexuality," in Antony Easthope and Kate McGowan eds., A Critical and Cultural Theory Reader. (Buckingham: Open University Press, 1992) pp. 90-5.

Gaines, Jane. "Women and Representation: Can We Enjoy Alternative Pleasure?" in Issues in Feminist Film Criticism, Patricia Erens, ed. [Indiana University Press: Indiana and Bloomington, 1990] pp. 75-92.

---.-."White Privilege and Looking Relations: Race and Gender in Feminist Film Theory." In Issues in Feminist Film Criticism, Patricia Erens, ed. [Indiana University Press: Indiana and Bloomington, 1990] pp. 197-214.

Gale, Peggy. "Video has captured our Imagination" in Video re-View eds. Peggy Gale and Linda Steele. [Art Metropole and V Tape: Toronto, 1996] pp. 114-21.

Gledhill, Christine, "Recent Developments in Feminist Criticism" in Film Theory and 
Criticism, Gerald Mast and Marshall Cohen eds., [Oxford University Press: NY and Oxford, 1985] pp. 817-845.

Haug, Kate. "Femme Experimentale: Interviews with Carolee Schneemann, Barbara Hammer, and Chick Strand" in Wide Angle vol. 20, No. 1, 1998, pp. 1-19.

Juhasz, Alexandra. "No Woman is an Object: Realizing the Feminist collaborative Video" in Camera Obscura 18.2 (2003) 70-97.

Johnston, Claire. "Women's Cinema as Counter-Cinema" in Movies and Methods: An Anthology, Bill Nichols, ed. [University of California Press: Berkeley, L.A. and London, 1976] pp. 208-217.

Kaplan, E. Ann. Women and Film [Methuen: NY and London, 1983].

-.--. "Feminist Film Criticism: Current Issues and Problems" in Studies in the Literary Imagination. Vol. 19, No. 1, Spring 1988. pp. 7-20.

Kuhn, Annette. "Textual Politics" in Women's Pictures: Feminism and Cinema [Routledge and Kegan Paul: London and NY, 1986] pp. 156-177.

Lauzen Martha M. STATISTICS ON WOMEN DIRECTORS, THE CELLULOID CEILING STUDY EXECUTIVE SUMMARY The Celluloid Ceiling: Behindthe-Scenes Employment of Women in the Top 250 Films of 2001, Revised 06.24.02 Found at http://www.5050summit.com/stats2001.html ( last accessed March 19, 2004).

Lesage, Julia. "The Political Aesthetics of the Feminist Documentary Film" in Issues in Feminist Film Criticism, Patricia Erens, ed. [Indiana University Press: Indiana and Bloomington, 1990] pp. 222-237.

----. "One Way or Another: Dialectical, Revolutionary, Feminist" in Jump Cut NO. 20, May 1978 found at http://www.uoregon.edu/ lesage/Juliafolder/OneWayOrAnother.html, last accessed 11/23/02.

MacDonald, Scott. "Interview with Sally Potter" in Camera Obscura, No. 35, May 1995, pp. 186-220.

Marchessault, Janine. "Feminist Avant-garde Cinema: From Introspection to Retrospection" in Cineaction No. 24/25, 1997, pp. 30-37.

Modleski, Tania. The Women Who Knew Too Much. (NY: Methuen) 1988.

Mulvey, Laura. "Visual Pleasure and Narrative Cinema", in Issues in Feminist 
Film Criticism, Patricia Erens, ed. [Indiana University Press: Indiana and Bloomington, 1990] pp. 28-40.

Nichols, Bill. "Documentary Film and the Modernist Avant-garde" in Critical Inquiry No. 27, Summer 2001, pp. 580-610.

Peek, Wendy Chapman. "Cherchez La Femme: The Searchers, Vertigo, and Masculinity in PostKinsey America" in Journal of American Culture, Summer 98, Vol. 21 No. 2. pp 73-88

Penley, Constance. "The Avant-garde and its Imaginary" in Movies and Methods: An Anthology vol. II, Bill Nichols, ed. [University of California Press: Berkeley, L.A. and London, 1985] pp. 576-601.

Penley, Constance and Lauren Bergstrom. "The Avant-garde: Histories and Theories" in Movies and Methods: An Anthology vol. II, Bill Nichols, ed. [University of California Press: Berkeley, L.A. and London, 1985] pp. 287-302.

Rabinovitz, Lauren. Points of Resistance: Women, Power \& Politics in the New York Avant-Garde Cinema [University of Illinois Press, 1991].

Rabinowitz, Paula. "Medium Uncool: Women Shoot Back; Feminism, Film and 1968--A Curious Documentary" in Science and Society vol. 65, No. 1, Spring 2000, pp. 7298.

---. "Seeing Through The Gendered I: Feminist Film Theory" in Feminist Studies vol. 16 , No. 1, Spring 1990, pp. 151-170

Rich, B. Ruby. Chick Flicks: Theories and Memories of the Feminist Film Movement. [Duke University Press: Durham and London, 1998].

Samuels, Robert. Hitchcock's Bi-textuality: Lacan, Feminisms, and Queer Theory. (Albany: State University of New York Press) 1998.

Shapiro, Michael J. "The Politics of Masculinity" in Cinematic Political Thought. [New York University Press: NY, 1999].

West, Ann. "The Concept of the Fantastic in Vertigo" in Hitchcock's Rereleased Films: From Rope to Vertigo, Walter Raubicheck and Walter Srebnick eds., (Detroit: Wayne State University Press) 1991. 163-174.

Wood, Robin. "'80s Hollywood: Dominant Tendencies" in CineAction!, No. 1. Spring 1985, pp 2-5. 